\title{
DAMPAK POLA ASUH ORANG TUA TERHADAP PERKEMBANGAN SOSIAL-EMOSIONAL ANAK
}

\author{
Jaja Suteja \\ Institut Agama Islam Negeri (IAIN) Syekh Nurjati Cirebon \\ E-mail:suteja@gmail.com \\ Yusriah \\ Institut Agama Islam Negeri (IAIN) Syekh Nurjati Cirebon \\ E-mail: yusriah@gmail.com
}

Article received: 10 Februari 2017 Review process: 21 Februari 2017

Article published: 28 Februari 2017

\begin{abstract}
Abstrak
Orang tua sebagai pendidik pertama, mempunyai kewajiban membimbing, melindungi serta membesarkan anak. Keberadaan orang tua sangatlah penting, sehingga peran orang tua merupakan dasar pertama dalam pembentukan pribadi anak. Upaya tersebut dapat terwujud apabila orang tua menerapkan pola asuh yang tepat, karena pola asuh yang diberikan kepada anak akan mempengerahui pekembangan sosial-emosional anak. Oleh karena itu, diperlukan pemahaman orang tua yang lebih terhadap perkembangan sosial-emosional anak, agar perkembangan sosial-emosional anak berkembang baik dan diterima di lingkungan masyarakat.

Hasil pembahasan ini menunjukkan bahwa terdapat tiga tipe pola asuh yang diterapkan orang tua di dalam mendidik anak yaitu demokratis, otoriter dan permisif. Ketiga pola asuh tersebut memiliki dampak yang berbeda terhadap perkembangan sosial-emosional anak. perbedaan tersebut ialah pola asuh demokratis lebih banyak memiliki dampak positif, sedangkan pola asuh otoriter dan permisif lebih banyak memiliki dampak yang negatif. Sehingga disarankan agar orang tua memimbing anak dengan pola asuh demokratis.
\end{abstract}

Kata Kunci : Pola Asuh, Perkembangan, Sosial-Emisonal

\section{A. PENDAHULUAN}

Mengasuh, membesarkan dan mendidik anak merupakan satu tugas mulia yang tidak lepas dari berbagai halangan dan tantangan. Anak merupakan individu unik yang mempunyai eksistensi dan memiliki jiwa sendiri, serta mempunyai hak untuk tumbuh dan berkembang secara optimal. Dunia anak selalu penuh kejutan, serba ingin tahu, selalu mengeksplorasi serta dunia bermain dan belajar. 
Masa kehidupan anak sebagian besar berada dalam lingkungan keluarga, karena itu keluargalah yang paling menentukan terhadap masa depan anak. Orang tua mempunyai tanggung jawab untuk mengantarkan putra-putrinya menjadi seorang yang sukses dan bagi orang tua penting memahami serta memperhatikan perkembangan anak agar anak berkembang dengan baik sehingga dalam perkembangannya anak bisa diterima di masyarakat. Allah SWT berfirman dalam Q.S. At-Tahrim ayat 6 yang artinya :

Artinya : "Wahai orang-orang yang beriman! peliharalah dirimu dan keluargamu dari api neraka yang bahan bakarnya adalah manusia dan batu; penjaganya malaikatmalaikat yang kasar dan keras yang tidak durhaka kepada Allah terhadap apa yang Dia perintahkan kepada mereka dan selalu mengerjakan apa yang diperintahkan" (Departemen Agama RI, 2006 : 560).

Di samping itu, orang tua yang memperlakukan anak sesuai dengan ajaran agama berarti memahami anak dari berbagai aspek, karena memahami anak-anaknya adalah bagian dari inti ajaran agama Islam. Cara memahami anak adalah dengan memberikan pola asuh yang baik, memberikan, perawatan dan kasih sayang agar anak dapat berkembang dengan baik.

Perkembangan anak tergantung pada bagaimana orang tua mengasuhnya. Apabila orang tua mengasuhnya dengan penuh kasih sayang dan bimbingan yang baik maka anak akan tumbuh dengan baik. Begitupun sebaliknya, apabila anak mendapatkan pengasuhan yang keras dan kasar maka anak pun menjadi keras dan kasar. (Rifa Hidayah, 2009 : 16)

Pola asuh meliputi interaksi antara orang tua dan anak dalam pemenuhan kebutuhan fisik dan psikologis (Wiwit Wahyuning dkk, 2003 : 126). Dalam interaksi dengan anak, orang tua cenderung menggunakan cara-cara tertentu yang dianggapnya paling baik bagi anak. Di sinilah letak perbedaan antara orang tua dalam mengasuh anak. Sebagian orang tua berfikir harus bisa menentukan pola asuh yang tepat dengan mempertimbangkan kebutuhan dan situasi anak. Kemudian sebagian orang tua lain juga mempunyai keinginan dan harapan untuk membentuk anak-anak berkembang menjadi seseorang yang dicita-citakan yang tentunya lebih baik dari orang tuanya.

Dalam proses mengasuh anak, setiap orang tua mempunyai sikap yang berbeda terhadap masing-masing anak mereka. Sikap tersebut berasal dari pengalaman dari calon orang tua di masa anak-anak dan menjadi nyata saat kehamilan terjadi. Sejalan dengan yang diungkapkan oleh Hurlock (66 : 1978) sikap orang tua terhadap anaknya dipengaruhi oleh konsep mereka 
mengenai peran menjadi orang tua. Hal tersebut tentu akan mempengaruhi cara mereka mengasuh anak dan berdampak pula pada perkembangan anak.

Perkembangan adalah rentetan perubahan jasmani dan rohani manusia menuju arah yang lebih maju dan sempurna (Alex Sobur, 2013 : 129). Adapun menurut Singgih D. Gunarsa (29 : 2014) perkembangan merupakan suatu proses yang mula-mula global, belum terpecah dan terperinci, kemudian semakin lama semakin banyak. Perkembangan pada anak berlangsung secara sistematis, progresif dan berkesinambungan. Artinya, perkembagan pada anak berarti perubahan yang bersifat saling mempengaruhi antara fisik dan psikis yang terjadi secara meningkat dan berlangsung dengan berurutan atau beraturan.

Salah satu aspek perkembangan pada diri anak yang perlu melibatkan bimbingan orang tua adalah pengembangan perilaku sosial-emosional. Sebagian besar orang tua menyadari adanya hubungan yang erat antara perilaku sosial-emosional anak dengan keberhasilan dan kebahagiaan pada masa kanak-kanak dan masa kehidupan selanjutnya. Untuk menjamin bahwa anak dapat melakukan penyesuaian dengan baik, orang tua memberikan kesempatan kepada anak untuk menjalin kontak sosial-emosional dengan anak yang lain, dan berusaha memotivasi anak agar aktif secara sosial.

Dalam proses perkembangan sosial-emosional anak, biasanya seorang anak belum memiliki kemampuan untuk bergaul dengan orang lain. Untuk mencapai kematangan sosial, anak harus belajar tentang cara-cara menyesuaikan diri dengan oang lain. Begitupun dengan emosi anak, meskipun emosi anak bersifat egosentris tetapi anak akan berkembang dengan sehat apabila dibimbing dengan penuh kasih sayang, sehingga dengan kasih sayang orang tua dan lingkungan keluarga yang baik anak akan mampu bersosialisasi dengan baik.

Orang tua menaruh perhatian yang sangat besar terhadap perilaku sosial-emosional seorang anak, karena anak yang diterima dengan baik mempunyai kemungkinan yang jauh lebih besar untuk mengerjakan sesuatu sesuai dengan kemampuannya dibandingkan dengan anak yang ditolak atau diabaikan oleh teman sebayanya. Setiap orang tua mempunyai harapan agar dalam masa perkembangan anaknya lebih baik dari pada masa kecilnya. Harapan tersebut dapat terwujud apabila orang tua mampu memahami karakter anak dan mengarahkannya, karena hal tersebut memang sudah menjadi kewajiban orang tua. Akan tetapi, ketika anak sudah mulai masuk PAUD / TK seringkali orang tua merasa memiliki persaingan antar orang tua apabila perkembangan anaknya masih di bawah perkembangan anak yang lain, sehingga yang timbul 
adalah ketidakmampuan untuk menahan diri agar tidak terburu-buru menyalahkan, melontarkan perasaan, bahkan memarahi anaknya (Ahmad Susanto, $2011: 16$ ).

Hal yang mungkin akan terjadi akibat orang tua yang tidak mampu menahan diri agar tidak cepat menyalahkan anak adalah perkembangan sosial-emosional anak yang mungkin akan terganggu. Adapun perkembangan sosial-emosional anak dapat dilihat melalui perilaku mereka ketika berada dilingkungan sosial, seperti kerja sama membereskan mainan, mengambilkan mainan temannya yang jatuh, berbagi jajanan, marah ketika pensilnya diambil teman, takut saat melihat orang yang tidak dikenal, gembira apabila diberikan pujian, sedih melihat temannya jatuh, serta merasa cemburu ketika temannya dekat dengan guru. Sikap orang tua yang terlalu mengekang atau bahkan selalu mengikuti apapun keinginan anak, akan mempengaruhi perkembangan sosial-emosional anak.

Fenomena di atas menunjukkan bahwa setiap orang tua memiliki cara yang berbeda dalam mengasuh anaknya, setiap cara pengasuhan tersebut akan berdampak pada proses perkembangan sosial-emosional anak. Karena anak usia 4 tahun mulai mengenali dunia luar selain keluarganya, mereka bersekolah, bersosialisasi dengan guru, teman, dan lingkungan sosial yang baru. Sehingga pola asuh yang orang tua berikan saat anak masih banyak menghabiskan waktu di rumah akan sangat mempengaruhi perkembangan sosial-emosional anak saat berada di lingkungan sosial yang baru.

\section{B. Pengertian Pola Asuh Orang Tua dan Perkembangan Sosial-Emosional Anak}

Menurut Sri Lestari (2013 : 49) pola asuh orang tua adalah serangkaian sikap yang ditunjukkan oleh orang tua kepada anak untuk menciptakan iklim emosi yang meliputi interaksi orang tua dan anak. Adapun menurut Havighurst (Aliyah Rasyid Baswedan, 2015 : 102) pola asuh orang tua adalah cara-cara pengaturan tingkah laku anak yang dilakukan oleh orang tuanya sebagai perwujudan dari tanggung jawabnya dalam pembentukan kedewasaan diri anak.

Sugihartono dkk, (2007) mengemukakan bahwa pola asuh adalah pola perilaku yang diterapkan pada anak dan bersifat konsisten dari waktu kewaktu. Pola asuh yang diterapkan tiap orang tua berbeda dengan keluarga lainnya. Pola perilaku ini dapat dirasakan oleh anak, dari segi positif dan negatif. Pola asuh juga dapat memberi perlindungan, dan mendidik anak dalam kehidupan sehari-hari. 
Sementara itu menurut Rohn (Aliyah Rasyid Baswedan, 2015 : 102) pola asuh adalah sikap orang tua dalam berinteraksi dengan anak-anaknya. Sikap tersebut dapat dilihat dari beberapa segi antara lain, (1) cara orang tua memberikan peraturan-peraturan, hadiah dan hukuman, (2) cara orang tua menunjukkan kekuasaan, dan (3) cara orang tua memberikan perhatian serta tanggap terhadap keinginan anak-anaknya.

Dari definisi di atas, dapat diambil pengertian bahwa pola asuh orang tua adalah sikap orang tua dalam memberikan pengaturan tingkah laku kepada anak sebagai perwujudan tanggung jawabnya dengan cara memberi peraturan, menunjukkan kekuasaan serta memberikan perhatian dan tanggap terhadap keinginan anak.

Menurut Desmita (2013:4) Perkembangan merupakan perubahan yang berlangsung secara terus-menerus dan bersifat tetap dari fungsi-fungsi jasmaniah dan rohaniah yang dimiliki individu menuju ke tahap kematangan melalui pertumbuhan, pematangan dan belajar. Sementara menurut Syamsu Yusuf (2001 : 15) (dalam Ahmad Susanto, 2011 : 19) perkembangan adalah perubahan-perubahan yang dialami oleh individu atau orgnisme menuju tingkat kedewasaannya atau kematangannya (maturition) yang berlangsung secara sistematis, progresif dan berkesinambungan, baik menyangkut fisik (jasmaniah) maupun psikis (rohanian).

Adapun menurut Kartini Kartono seperti yang dikutip oleh Alex Sobur (2003 :128) perkembangan adalah perubahan-perubahan psikofisis sebagai hasil dari proses pematangan dari fungsi-fungsi psikis dan fisis pada diri anak, yang ditunjang oleh faktor lingkungan dan proses belajar dalam rentan waktu tertentu menuju kedewasaan.

Dari definisi di atas dapat diambil pengertian bahwa perkembangan merupakan perubahan yang dilalui dengan proses kematangan belajar, sehingga setiap masa perkembangan akan mempengaruhi perkembangan selanjutnya.

Sedangkan perkembangan sosial menurut Elisabeth B. Harlock (250 : 1978) adalah perolehan kemampuan berperilaku yang sesuai dengan tuntutan sosial. Sementara itu menurut Syamsu Yusuf (122 : 2012) perkembangan sosial merupakan pencapaian kematangan dalam hubungan sosial. Dapat juga diartikan sebagai proses belajar untuk menyesuaikan diri terhadap norma-norma kelompok, moral, dan tradisi; meleburkan diri menjadi suatu kesatuan dan saling berkomunikasi serta bekerjasama. Perilaku sosial adalah perilaku yang menunjukkan atau 
memperlihatkan, menerima, mengakui, menyetujui serta melaksanakan norma-norma yang berlaku dimana individu berada (Abu Ahmadi : 2001)

Dari pengertian di atas dapat disimpulkan bahwa perkembangan sosial adalah pencapaian kemampuan berperilaku dalam hubungan sosial melalui proses belajar untuk menyesuaikan diri terhadap norma kelompok, moral dan tradisi. Sehingga mampu meleburkan diri menjadi suatu kesatuan dan saling berkomunikasi serta bekerjasama.

Selanjutnya pengertian emosi menurut Sarlito Wirawan Sarwono (Syamsu Yusuf, 115 : 2012) adalah setiap keadaan pada diri seseorang yang disertai warna afektif baik pada tingkat lemah maupun pada tingkat yang luas (mendalam). Adapun menurut Sukmadinata (Ahmad Susanto, 135 : 2011) emosi merupakan perpaduan dari beberapa perasaan yang mempunyai intenitas yang relatif tinggi dan menimbulkan suatu gejolak suasana batin.

Ahmad Susanto (135 : 2011) emosi adalah perasaan batin seseorang, baik berupa pergolakan pikiran, nafsu, keadaan mental dan fisik yang dapat muncul atau bermanifestasi kedalam bentuk-bentuk atau gejala-gejala seperti takut, cemas, marah, murung, kesal, iri, cemburu, senang, kasih sayang, dan ingin tahu

Dari beberapa pengertian emosi di atas, dapat disimpulkan bahwa emosi anak adalah keadaan perasaan pada diri seorang anak yang disertai warna afektif, baik berupa pergolakan pikiran, nafsu, keadaan mental, maupun fisik yang dapat dilihat melalui gejala-gejala seperti marah, bahagia, sedih, kasih sayang, ingin tahu, dan cemburu.

\section{Tipe Pola Asuh Orang Tua Terhadap Anak}

Menurut Hurlock (2008 : 205) ada tiga tipe pola asuh orang tua terhadap anak di antaranya :

\section{a. Pola asuh otoriter}

Pola asuh yang menerapkan semua keputusan berada ditangan orang tua bahkan dibentuk oleh orang tua. Artinya, tipe pola asuh otoriter ini kekuasaan orang tua sangat dominan, karena selalu menuntut anaknya menjadi seperti yang dikehendaki, apabila anak tidak mematuhi orang tua maka akan mendapat hukuman.

\section{b. Pola asuh demokratis}


Biasanya, orang tua yang menanamkan nilai-nilai demokratis dalam mengasuh anak akan menjunjung keterbukaan, pengakuan terhadap pendapat anak, dan kerjasama. Anak diberi kebebasan, tetapi kebebasan yang dapat dipertanggung jawabkan.

\section{c. Pola asuh permisif}

Pola asuh yang permisif yaitu pola asuh di mana orang tua memberikan kebebasan penuh kepada anak. Sehingga anak menjadi pribadi yang semaunya sendiri.

Pola asuh orang tua merupakan hal pertama yang akan membentuk bagaimana anak setelah dewasa, karena setiap sikap orang tua dalam mengasuh anak akan mempengaruhi perkembangan anak. Menurut J.P Chaplin (dalam Alex Sobur : 2013) perkembangan adalah tahapan-tahapan perubahan yang progresif dan ini terjadi dalam rentang kehidupan manusia dan organisme lainnya, tanpa membedakan aspek-aspek yang terdapat dalam organisme-organisme tersebut.

Sedangkan tipe pola asuh menurut Diana Baumrind, (Desmita, 2012 : 144-145) sangat dikaitkan dengan aspek-aspek yang berbeda dalam tingkah laku anak, yaitu :

1) Pola asuh otoritatif (authoritative parenting) adalah salah satu gaya pengasuhan yang memperlihatkan pengawasan ektra ketat terhadap tingkah laku anak, tetapi orang tua juga bersikap responsif, menghargai dan menghormati pemikiran, perasaan serta mengikutsertakan anak dalam pengambilan keputusan.

2) Pola asuh otoriter (authoritarian parenting) adalah suatu gaya pengasuhan yang membatasi dan menuntut anak untuk mengikuti perintah-perintah orang tua.

3) Pola asuh permisif (permissive parenting) yaitu gaya pengasuhan yang dibedakan dalam dua bentuk, yaitu : (a) pengasuhan permissive-indulgent yaitu suatu gaya pengasuhan dimana orang tua sangat terlibat dalam kehidupan anak, tetapi menetapkan sedikit batas atau kendali atas mereka. (b) pengasuhan permissive-different, yaitu gaya pengasuhan dimana orang tua sangat tidak terlibat dalam kehidupan anak.

Berdasarkan pendapat para ahli, dapat disimpulkan bahwa secara umum ada tiga macam pola asuh yang diterapkan oleh orang tua kepada anaknya, yaitu pola asuh demokratis, pola asuh otoriter dan pola asuh permisif. Pola asuh demokratis yaitu gaya pengasuhan yang dilakukan orang tua dengan mempercayai bahwa seorang anak memiliki kemampuan untuk 
mengembangkan dirinya agar tidak bergantung pada orang tua. Sedangkan pola asuh otoriter merupakan cara pengsuhan yang membatasi anak dengan menerapkan aturan-aturan yang ketat yang harus ditaati oleh anak dan pola asuh permisif adalah gaya pengasuhan yang ditandai dengan sikap orang tua yang cenderung melepaskan anak. Artinya, kontrol orang tua terhadap perkembangan anak sangat rendah.

Ciri-ciri pola asuh orang tua menurut Baumrind (Iriani Indri Hapsari : 2016) adalah sebagai berikut :

(1) Pola asuh demokratis

a. Mendukung anak menjadi mandiri tetapi tetap menempatkan batasan dan kontrol pada tindakan anak

b. Memperbolehkan diskusi yang cukup banyak

c. Orang tua hangat dan peduli pada anak

d. Kedudukan anatara orang tua dan anak dalam berkomunikasi sejajar

e. Suatu keputusan diambil bersama dengan mempertimbangkan keuntungan kedua belah pihak

f. Anak diberi kebebasan yang bertanggung jawab, artinya apapun yang dilakukan anak tetap harus ada dibawah pengawasan orang tua dan dapat dipertanggungjawabkan secara moral.

g. orang tua dan anak tidak dapat memaksakan sesuatu tanpa berkomunikasi terlebih dahulu

h. setiap pengambilan keputusan disetujui oleh keduanya tanpa ada yang merasa tertekan.

(2) Pola asuh otoriter

a. Orang tua menghukum tanpa alasan

b. Menuntut anak agar mengikuti arahan mereka tanpa menghargai kerja dan usaha

c. Membatasi aktifitas anak

d. Orang tua bertindak semaunya tanpa dapat dikritik oleh anak

e. Anak harus menurut dan tidak boleh membantah terhadap apa-apa yang diprintahkan atau dikehendaki oleh orang tua

f. Anak tidak diberi kesempatan menyampaikan apa yang dipikirkan, diinginkan atau dirasakannya. 
(3) Pola asuh permisif

a. Sangat tidak terlibat dalam kehidupan anak

b. Orang tua harus mengikuti keinginan anak baik orang tua setuju atau tidak

c. Apa yang diinginkan anak selalu dituruti dan diperbolehkan orang tua

d. Anak cenderung menjadi bertindak semena-mena.

\section{Faktor-faktor yang Mempengaruhi Pola Asuh Orang Tua}

Kebanyakan sikap orang tua terhadap anak dan sikap menjadi orang tua berasal dari pengalaman calon orang tua dimasa kanak-kanaknya dan menjadi nyata bila kehamilan terjadi. Sikap orang tua terhadap anaknya dipengaruhi oleh konsep mereka mengenai peran menjadi orang tua. Menurut Hurlock (68 : 1978) Faktor-faktor penting yang mempengaruhi pola asuh orang tua adalah sebagai berikut :

a. Keinginan untuk mendapat anak

Sebagian orang menginginkan banyak anak, yang lain hanya menginginkan sedikit atau sama sekali tidak. Beberapa diantaranya merasa perkwinannya tidak lengkap tanpa anak dan yang lain merasa bahwa anak hanya merupakan hambatan terhadap keberhasilan pekerjaan atau kenaikan tersebut. Hal tersebut akan berpengaruh dalam proses pengasuhan terhadap anak.

b. Keadaan fisik selama kehamilan

Apabila calon ibu merasa sehat dan sedikit menderita gangguan walaupun beberapa gangguan itu lazim terjadi, ia mungkin lebih bersikap menguntungkan daripada calon ibu yang banyak menderita gangguan.

c. Keadaan selama kehamilan

Bagi banyak wanita, kehamilan merupakan saat depresi, kecemasan, dan khawatir tentang kelahiran anak, mempunyai anak yang cacat, atau ketidakmampuan untuk menjadi seorang ibu. Bagi yang lain, keadaan selama kehamilan tersebut merupakan saat penantian yang bahagia.

d. Mimpi dan fantasi calon ibu

Rasa takut, keraguan, dan kecemasan untuk memiliki anak yang dialami calon ibu sering diperkuat oleh mimpi dan fantasi. 
e. Pengalaman awal dengan anak

Calon orang tua yang mempunyai pengalaman merawat saudaranya akan cenderung mempunyai sikap yang kurang menerima dalam hal mempunyai anak daripada mereka yang tidak mempunyai pengalaman tersebut.

f. Sikap dan pengalaman teman

Teman-teman yang mempunyai pengalaman yang tidak menyenangkan di rumahnya dan tidak bahagia dalam perannya sebagai orang tua dapat mempengaruhi sikap calon orang tua.

g. Konsep tentang anak yang diinginkan

Bila orang tua mempunyai konsep yang diinginkan mengenai calon anak, akan memungkinkan munculnya rasa kecewa dan tidak senang apabila anak tersebut tidak sesuai dengan konsep yang diinginkan.

h. Kelas sosial orang tua

Banyak orang tua dari kelas rendah cenderung menganggap menjadi orang tua sebagai "akibat yang tak terelakkan karena hubungan kelamin". Sedangkan mereka yang berasal dari kelas menengah dan kelas atas menganggapnya sebagai "pemenuhan" suatu perkawinan.

i. Status ekonomi

Jika kondisi keuangan terbatas, sikap orang tua terhadap kedatangan seorang anak akan terpengaruh.

j. Usia orang tua

Secara umum orang tua yang lebih berumur menerima perannya sepenuh hati daripada mereka yang lebih muda.

k. Minat dan aspirasi calon ibu

Wanita yang aspirasi utamanya adalah untuk menjadi ibu yang lebih baik mempunyai sikap menguntungkan terhadap calon anaknya daripada wanita yang perhatiannya mengutamakan dan memusatkan pada kegiatan sosial atau pekerjaan.

1. Media massa

Berbagai media massa seperti buku, majalah, film, radio dan televisi cenderung memberikan gambaran yang romantis tentang anak dan orang tua. Wanita biasanya cenderung lebih dipengaruhi oleh gambaran media tersebut daripada pria. 


\section{E. Dampak Pola Asuh Orang Tua terhadap Perkembangan Sosial-Emosional Anak}

Menurut Diana Baumrind (Iriani Indri Hapsari : 2016) dampak gaya pengasuhan orang tua terhadap perkembangan anak adalah sebagai berikut :

a. Pola asuh otoriter.

- Dampak positif

Pola asuh ini lebih banyak memiliki dampak negatif, akan tetapi pola asuh ini pun memiliki dampak positif. Dampak positifnya adalah anak akan lebih disiplin karena orang tua bersikap tegas dan memerintah.

- Dampak negatif

Anak yang diasuh dengan gaya pengasuhan ini sering terlihat tidak bahagia, dan cemas dengan perbandingan antara mereka dengan anak lain, gagal dalam inisiatif kegiatan, dan lemah dalam kemampuan komunikasi sosial.

b. Pola asuh demokratis.

- Dampak positif

Anak yang diasuh dengan gaya pengasuhan ini sering terlihat ceria, memiliki pengendalian diri dan kepercayaan diri, kompetn dalam bersosialisasi, berorientasi prestasi, mampu mempertahankan hubungan yang ramah, bekerja sama dengan orang dewasa, dan mampu mengendalikan diri dengan baik.

- Dampak negatif

Walaupun pola asuh demokratis lebih banyak memiliki dampak positif, namun terkadang juga dapat menimbulkan masalah apabila anak atau orang tua kurang memiliki waktu untuk berkomunikasi. Oleh karena itu,diharapkan orang tua tetap meluangkan waktu untuk anak dan tetap memantau aktivitas anak. Selain itu, emosi anak yang kurang stabil juga akan menyebabkan perselisihan disaat orang tua sedang mencoba membimbing anak.

c. Pola asuh permisif.

- Dampak positif

Orang tua akan lebih mudah mengasuh anak karena kurangnya kontrol terhadap anak. Bila anak mampu mengatur seluruh pemikiran, sikap, dan tindakannya dengan baik, kemungkinan kebebasan yang diberikan oleh orang tua dapat dipergunakan untuk 
mengembangkan kreatifitas dan bakatnya, sehingga ia menjadi seorang individu yang dewasa, inisiatif, dan kreatif. Dampak positif tergantung pada bagaimana anak menyikapi sikap orang tua yang permisif.

- Dampak negatif

Dampak dari gaya pola asuh permisif adalah anak mengembangkan perasaan bahwa orang tua lebih mementingkan aspek lain dalam kehidupan daripada anaknya. Oleh karenanya, anak banyak yang kurang memiliki kontrol diri dan tidak dapat mengatasi kemandirian secara baik. Mereka memiliki harga diri yang rendah, tidak matang, dan mungkin terisolasi dari keluarga. Pada saat remaja mereka memperlihatkan kenakalan. Anak jarang belajar menghormati orang lain dan memiliki kesulitan dalam mengendalikan tingkah laku mereka. Mereka bisa menjadi agresif, mendominasi.

Pola asuh orang tua diapresiasi anak sebagai undangan, bantuan, bimbingan, dan dorongan untuk membentuknya mengembangkan diri sebagai pribadi yang berkarakter adalah orang tua yang mampu memancarkan kewibawaan pada anak. Orang tua yang mampu berbuat demikian senantiasa menampilkan perilaku yang konsisten antara bahasa lisan dan perbuatannya, menerima anak apa adanya, dan menghargai yang dimiliki serta dilakukan anak. Orang tua yang menerima anak apa adanya dapat dikatakan melakukan upaya untuk membantu anak memiliki karakter positif dengan menyadarkan upayanya berdasarkan kata hati yang bererilaku sekaligus secara bersama-sama antara dirinya dengan anak yang menampilkan karakter positif. Dengan karakter yang positif akan menciptakan perilaku yang positif. (Moh. Shochib : 2010).

Bunda Novi dalam bukunya yang berjudul "cara-cara mengasuh anak yang sering diabaikan orang tua" menyatakan pada dasarnya, anak adalah manusia seutuhnya yang di dalam dirinya terdapat hak-hak yang harus diperhatikan dan dipenuhi, khususnya oleh orang tua. Pemenuhan hak-hak tersebut hanya bisa tercapai jika orang tua tidak abai terhadap pola asuh yang benar dalam membesarkan seorang anak. Selain itu, dasar dari perkembangan kehidupan anak adalah adanya perlindungan terhadap kelangsungan hidup dan tumbuh kembangnya. Hal ini menjadi penting agar anak dapat tumbuh dan berkembang menjadi anak yang kreatif, inovatif, hidup sejahtera, dan tentunya memiliki masa depan yang berkualitas. 
Berdasarkan pola asuh orang tua dan perilaku sosial-emosional anak tersebut, maka dampak dari pola asuh orang tua terhadap perkembangan sosial-emosional anak adalah sebagai berikut :

1. Pola asuh demokratis berdampak positif pada perkembangan anak, hal tersebut dapat dilihat dari perilaku sosial-emosional anak yang ceria, mandiri, mudah berteman, mau berbagi, pemberani, memiliki motivasi yang baik dan mau bekerja sama.

2. Dampak pola asuh permisif pada perkembangan anak yaitu anak semaunya sendiri, sulit dikendalikan, tidak bisa mengontrol diri, sulit diajak bekerjasama, belum bisa mandiri.

3. Pola Asuh otoriter membuat anak tidak ceria, lebih banyak diam, selalu patuh, tidak bisa mengambil keputusan, mengandalkan orang lain, tidak berani membela diri, dan geraknya tidak bebas.

\section{F. Simpulan}

Berdasarkan hasil pembahasan yang telah dijelaskan di atas, dapat ditarik kesimpulan :

a. Sikap orang tua antar satu dan lainnya dalam mengasuh anak memiliki perbedaan, hal tersebut terjadi karena setiap orang tua memiliki pendapat yang berbeda dalam mendidik anaknya. Sebagian orang tua berpendapat menuntut anak adalah cara terbaik agar anak menjadi patuh, tetapi menurut sebagian yang lain tidak. Karena itu satu pola asuh yang berhasil diterapkan oleh salah satu orang tua belum tentu bisa diterapkan dengan baik oleh orag tua yang lain.

b. Perkembangan sosial-emosional anak dengan kecenderungan pola asuh demokratis berkembang baik, sementara anak dari orang tua yang cenderung permisif masih belum menunjukkan perilaku sosial-emosional. Begitupun dengan anak dari orang tua yang cenderung otoriter, perilaku sosial-emosionalnya masih belum muncul.

c. Dampak dari pola asuh orang tua yang demokratis terhadap perkembangan sosial-emosional anak adalah anak mudah berteman, mau diajak bekerja sama, mandiri, serta mau berbagi. Sementara itu, anak dari orang tua yang permisif cenderung berperilaku manja, mudah marah, tidak mau berbagi dan belum bisa mandiri. Adapun anak dari orang tua yang cenderung bersikap otoriter yaitu tidak berani dalam mengambil keputusan, lebih banyak diam dan selalu bergantung pada perintah orang lain.

\section{DAFTAR PUSTAKA}

Abu Ahmadi \& Widodo Supriyono. 2004. "Psikologi Belajar”. Jakarta : Rineka Cipta. 
Ahmad Susanto. 2011. “Perkembangan Anak Usia Dini”.Jakarta : Prenada Media Group.

Alex Sobur. 2013. "PsikologiUmum”. Bandung : Pustaka Setia.

Aliah Rasyid Baswedan. 2015. "Wanita, Karir dan Pendidikan Anak”. Yogyakarta : Ilmu Giri.

Bunda Novi. 2015. "Cara-cara Mengasuh Anak Yang Sering Diabaikan Orang Tua”. Yogyakarta : Flash Books

Departemen Agama Ri. 2006. “Al-Qur'an Terjemah Bahasa Indonesia”. Kudus : Menara Kudus. Desmita. 2013. "Psikologi Perkembangan”. Bandung : Remaja Rosdakarya.

Elizabeth B. Hurlock. 1978.“Perkembangan Anak Jilid I Edisi Keenam”. PT Gelora Aksara

Elizabeth B. Hurlock. 1978.“Perkembangan Anak Jilid II Edisi Keenam”. PT Gelora Aksara Iriani Indri Hapsari. 2016. "Psikologi Perkembangan Anak”. Jakarta : PT Indeks.

Muazar Habibi. 2015. “Analisis Kebutuhan Anak Usia Dini”. Yogyakarta : Deepublish.

Moh. Shochib. 2010. "Pola Asuh Orang Tua (Dalam Membantu Anak Mengembangkan Disilin Diri Sebagai Pribadi Yang Berkarakter”. Jakarta : PT Rineka Cipta.

Rifa Hidayah. 2009. “Psikologi Pengasuhan Anak”. Malang : Uin-Malang Press.

Singgih D. Gunarsa. 2014. "Dasardan Teori Perkembangan Anak”. Jakarta : Bpk Gunung Mulia.

Sri Lestari. 2013. "Psikologi Keluarga”. Jakarta : Kencana Prenada Media Group.

Sugihartono, dkk. 2007. "Psikologi Pendidikan”. Yogyakarta : UNY Press

Syamsu Yusuf. 2012. "Psikologi Perkembangan Anak Dan Remaja”. Bandung : PT Remaja Rosdakarya.

Tony Setiabudi \& Hardywinoto. 2003. “Anak Unggul Berotak Prima”. Jakarta : PT Gramedia Pustaka Utama.

Wiwit Wahyuning, Dkk. 2003.“Mengkomunikasikan Moral Kepada Anak”. Jakarta : Elex Media Komputindo. 